\title{
The expression and prognostic significance of the fumour-associated glycoprotein 72 in the normal, hyperplastic and neoplastic endometrium using immunohistochemical methods
}

\section{Ekspresja i znaczenie prognostyczne glikoproteiny 72 towarzyszq̨cej nowotworom ocenianej metodami immunohistochemicznymi w normalnym, rozrostowym i nowotworowym endometrium}

\author{
Tolga Mızrak ${ }^{1}$, Ahmet Uysal', ${ }^{1,}$, Cüneyt Eftal Taner ${ }^{1}$, Ümit Bayol ${ }^{3}$ \\ ${ }^{1} \mathrm{MH}$ Aegean Maternity and Teaching Hospital, Department of Obstetrics and Gynecology, Izmir, Turkey \\ ${ }^{2}$ Çanakkale Onsekiz Mart University, Department of Obstetrics and Gynecology, Çanakkale, Turkey \\ ${ }^{3} \mathrm{MH}$ Aegean Training and Teaching Hospital, Department of Pathology, Izmir, Turkey
}

Przegląd Menopauzalny 2013; 3: 202-206

\section{Summary}

Aim of the study: Our aim was to investigate the expression and the prognostic significance of tumourassociated glycoprotein 72 (TAG-72), which is an epithelial tumour marker, using immunohistochemical methods in the normal, hyperplastic and neoplastic endometrium.

Material and methods: The study group comprised of 47 cases with simple non-atypical hyperplasia and normal endometrium $(n=17)$, complex non-atypical hyperplasia $(n=10)$, and endometrial adenocarcinoma $(n=21)$. The epithelial tumour marker TAG-72 was determined by immunohistochemical methods. The location of TAG-72 in the differential diagnosis and its prognostic value were statistically analyzed.

Results: The immunoreactivity of the immunohistochemical dye was evaluated in terms of the pattern, intensity and pattern + intensity. The comparison between the three groups showed that there was a significant difference in terms of pattern $(p<0.001)$, intensity $(p<0.001)$ and pattern + intensity $(p<0.001)$. The marker TAG-72 was not found to be a prognostic marker for endometrial adenocarcinoma.

Conclusions: The marker TAG-72 is a reliable parameter and marker for the differentiation of the neoplastic endometrium from the non-neoplastic and hyperplastic endometrium. There is a significant relationship between the increasing age and staining pattern of the TAG-72 expression. Still, TAG-72 does not seem to be an independent prognostic factor for the endometrial carcinoma.

Key words: TAG-72, prognostic factor, endometrium.

\section{Streszczenie}

Cel pracy: Celem pracy było badanie ekspresji i prognostycznego znaczenia glikoproteiny towarzyszącej nowotworom 72 (TAG-72), która jest markerem nowotworów nabłonkowych, przy zastosowaniu metod immunohistochemicznych w prawidłowym, rozrostowym i nowotworowym endometrium.

Materiał i metody: Badaniem objęto 47 przypadków z rozrostem prostym bez atypii i prawidłowym endometrium $(n=17)$, rozrostem złożonym bez atypii $(n=10)$ oraz rakiem endometrium $(n=21)$. TAG-72 oznaczano metodami immunohistochemicznymi, a jego rolę w diagnostyce różnicowej i wartość prognostyczną analizowano statystycznie.

Wyniki: Immunoreaktywność immunohistochemicznej reakcji barwnej oceniano w warunkach kształtu, intensywności i kształtu + intensywności. Porównanie grup wykazało istotną różnicę kształtu $(p<0,001)$, intensywności $(p<0,001)$ i ksztattu + intensywności $(p<0,001)$. Marker TAG-72 nie spełnia kryteriów prognostycznego markera dla raka endometrium.

Wnioski: Marker TAG-72 jest miarodajnym parametrem i markerem dla różnicowania nowotworowego endometrium od nienowotworowego i rozrostowego endometrium. Istnieje istotny związek pomiędzy rosnącym wiekiem i ekspresją TAG-72. Pomimo to TAG-72 nie wydaje się być niezależnym prognostycznym czynnikiem raka endometrium.

Słowa kluczowe: TAG-72, czynnik prognostyczny, endometrium. 


\section{Introduction}

Endometrial hyperplasia (EH), is a histopathological condition, which is characterized by a proliferation of endometrial glandular epithelium and stroma, depending on estrogen hyperstimulation, with a potential for malignant transformation [1]. Endometrial hyperplasia is divided into four groups according to the World Health Organization (WHO) classification: simple nonatypical hyperplasia, complex non-atypical hyperplasia, simple atypical hyperplasia, and complex atypical hyperplasia. Hysterectomy is usually recommended for cases with an atypical hyperplasia, because of the coexistence of adenocarcinoma in 50\% of the cases [2-4].

Recent studies have revealed that less than $5 \%$ of simple and complex non-atypical hyperplasia cases undergo malignant transformation in the long term (20 years), whereas this percentage increases to $30 \%$ when there is an atypical hyperplasia $[5,6]$.

According to the revised FIGO criteria (2009), the risk factors for endometrial carcinoma are the stage, depth of the myometrial invasion, lymphovascular invasion, histological grade, and lymph node involvement [7].

However, as the process of oncogenesis has been understood better, the cytogenetic and molecular events have emerged more clearly in this process, and the prognostic and therapeutic assessment has become more precise [8]. The studies with immunohistochemical and molecular markers have helped to understand tumour development.

The human endometrium shows characteristic morphological changes during the menstrual cycle. This results in different immunoreactivity of the endometrium against antigens in different phases. The normal and transformed morphology of the endometrial cells are affected by conditions such as hormonal status, infection, and contraception, which lead to subjective interpretations of the cytopathological changes. The use of antibodies against well-described antigens related to tumours enhances the performance in the cytopathological and histopathological diagnosis of carcinomas such as the endometrial carcinoma [9].

The marker TAG-72 has a high molecular weight, is mucin-like, and has IgG-type monoclonal antibody against the Tumour Associated Glycoprotein-72 (TAG-72). It was defined as one of the 11 antibodies that act against human breast cancer cells. It is primarily located in the extracellular matrix of neoplastic tumours. This glycoprotein is generally not expressed in normal tissues [10, 11].

Previous studies have demonstrated that it frequently reacts with the carcinoma of the breast, lung, ovaries, and the gastro-intestinal tract [10-12]. Some researchers have found that TAG-72 is expressed in the endometrium in different phases, and shows periodic staining properties. This feature is also reactivated by the cellular changes in the normal, hyperplastic and neo-plastic endometrium [9-13]. Although the pathogenetic link between hyperplasia and malignancy has not been explained clearly, it is known that hyperplasia is a precursor for malignancy. Based on these hypotheses, some researchers have proposed that cases with endometrial hyperplasia, which react with TAG-72, should be candidates for more frequent controls and more invasive diagnostic procedures.

In this study, biopsy samples from patients diagnosed with simple and complex hyperplasia and with carcinoma, TAG-72 expression, which is an epithelial tumour marker, was determined using immunohistochemical methods, in search of more precise methods for differential diagnosis.

\section{Material and methods}

The study subjects consisted of 47 patients, who were admitted to our hospitals, obstetrics and gynaecology clinics and the oncology clinic, and were operated on due to various gynaecological reasons, such as metrorrhagia or post-menopausal bleeding. This study was prospective and necessary permissions from the ethical committee of our hospital and informed consent from the patients that compose our study group were taken.

\section{Patient selection}

According to the endometrial biopsy results, which were carried out under local anaesthesia with Pipelle, 21 patients had endometrial adenocarcinoma, $10 \mathrm{pa}-$ tients - complex endometrial hyperplasia, 9 patients - simple endometrial hyperplasia, 8 patients - normal endometrium ( 5 in secretion phase and 3 in proliferation phase).

All these cases were included in the study. In one case, both simple and complex hyperplasia foci were identified. This patient participated in both groups. All biopsies were divided into three groups:

- group I: simple non-atypical hyperplasia and normal endometrium group ( $n=17)$,

- group II: complex non-atypical hyperplasia group $(n=10)$,

- group III: endometrial carcinoma group $(n=21)$.

\section{Methods}

For all groups, the age, first menstruation age, number of pregnancies, parity, use of oral contraceptives, use of hormone replacement therapy, and smoking, and immunohistochemical staining characteristics of paints and postoperative staging for tumour grade and myometrial invasions were recorded.

Biopsies from patients were fixed in $70 \%$ ethyl alcohol for 24 hours. The tissue samples were dehydrated 
with an alcohol series of increasing alcohol percentages. After the transparency process with xylene, the tissue samples were embedded in paraffin. The 5-7 micron thick sections obtained from the paraffin blocks were divided into two groups in order to be stained, by histochemical and immunohistochemical techniques.

For the histological assessment of tissue sections, they are stained with hematoxylin-eosin (HE). Once the samples were examined and the pathological diagnosis was complete, immunohistochemical staining was performed. When the immunohistochemical methods were applied, for each sample, one cross-section was retained as a negative control. During the evaluation of the groups, the results were evaluated as negative, focal (less than 50\% staining) and diffuse (more than 50\% staining) according to the staining pattern of the immunoreactivity, and as negative, weakly positive (+) and strongly positive $(++)$ according to the intensity (Fig. 1).

\section{Statistical analyses}

Group III was compared with group I + group II, and the results for all three groups were compared statisti-

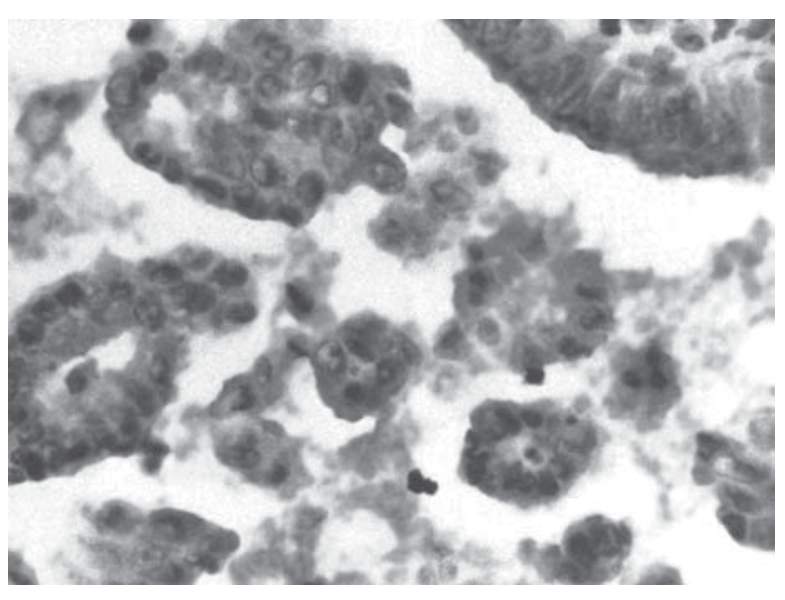

Fig. 1. PAP $\times 250$, in the neoplastic tissue cytoplasmic and luminal positivity of TAG-72

Tab. I. Statistical analyses of clinical characteristics of the groups

\begin{tabular}{|c|c|c|c|c|}
\hline & Group I & Group II & Group III & $P$ \\
\hline $\begin{array}{l}\text { Age of } \\
\text { the first } \\
\text { menstruation }\end{array}$ & $13.8(13-16)$ & $12.9(12-14)$ & 13.8 (11-18) & 0.089 \\
\hline $\begin{array}{l}\text { Oral contra- } \\
\text { ceptives }\end{array}$ & $17.6(3)$ & $20.0(2)$ & $23.8(5)$ & 0.895 \\
\hline Smoking & 23.5 (4) & $50.0(5)$ & $19.0(4)$ & 0.178 \\
\hline DM & $17.6(3)$ & $20.2(2)$ & $19.0(4)$ & 0.988 \\
\hline $\mathrm{HT}$ & $11.8(2)$ & $40.0(4)$ & $38.1(8)$ & 0.144 \\
\hline \multicolumn{5}{|c|}{$\begin{array}{l}D M-\text { diabetes mellitus; } H T \text { - hypertension } \\
\text { Group I: simple non-atypical hyperplasia and normal endometrium group } \\
(n=17) \\
\text { Group II: complex non-atypical hyperplasia group }(n=10) \\
\text { Group III: endometrial carcinoma group }(n=21)\end{array}$} \\
\hline
\end{tabular}

cally with each other. The use of oral contraceptives, hormone replacement therapy, smoking, and a history of diabetes mellitus and hypertension were evaluated with the $\chi^{2}$ test. The immunoreactivity of the immunohistochemical dye was evaluated with the Kruskal Wallis and the Mann-Whitney test. For the TAG-72 of the endometrial carcinoma cases, a monoclonal antibody (Neomarker) was used.

\section{Results}

The study groups were comprised of 48 biopsies, which were obtained from 47 patients. The median ages of groups were as follows: group I: 45 (38-56), group II: 46 (41-50) and group III: 59 (43-83). Using the $\chi^{2}$ test, there was no significant difference between the groups in terms of OK, hormonal replacement therapy (HRT), smoking and history of DM/HT. The statically analyses of clinical characteristics of the groups are presented in Table I.

The immunoreactivity of the immunohistochemical dye was evaluated in terms of the pattern, intensity and pattern + intensity. The comparison between the three groups was performed using the Kruskal-Wallis test. There was a significant difference between the groups in terms of pattern $(p<0.001)$, intensity $(p<0.001)$ and pattern + intensity $(p<0.001)$ (Tab. II). With the MannWhitney Test for binary comparison, there was a statistically significant difference found between group III and group II + group I $(p<0.001)$.

In the 21 cases with endometrial adenocarcinoma, the mean age was $59.06 \pm 9.36$ years (43-83). The age and prognostic factors of the cases were compared with the intensity and pattern of TAG-72 using the one-way analysis of variance. There was no relationship between the prognostic factors and the immunoreactivity, whereas there was a significant difference between the age and the staining pattern p: $0.023(p<0.05)$ (Tab. III).

Tab. II. The comparison of the three groups in terms of immunoreactivity and immunohistochemical evaluation

\begin{tabular}{lcccc}
\hline TAG-72 & Group I & Group II & Group III & $P$ \\
\hline Pattern & 20.03 & 14.50 & 32.88 & 0.000 \\
\hline Intensity & 20.38 & 14.50 & 32.60 & 0.000 \\
\hline Pattern \& Intensity & 20.26 & 14.50 & 32.69 & 0.000 \\
\hline${ }^{*} P<0.05$ is significance & & & &
\end{tabular}

Tab. III. The relationship between the prognostic factors of endometrial cancer and the immunoreactivity

\begin{tabular}{lcc}
\hline & Pattern ( $p$ value) & Intensity ( $p$ value) \\
\hline Age & 0.023 & 0.828 \\
\hline Stage & 0.159 & 0.360 \\
\hline Grade & 0.838 & 0.554 \\
\hline Myometrial invasion & 0.390 & 0.386 \\
\hline$p<0.05$ is significance & &
\end{tabular}




\section{Discussion}

Excessive amounts of TAG-72 are expressed in colorectal, gastrointestinal, bladder, salivary gland, breast, and ovarian, cancers. This antibody is used in various clinical oncological applications. It is a guiding parameter in the serological follow-up of colorectal and ovarian cancers, and in finding the primary focus in the malignant peritoneal effusion [10-12, 14-17].

Currently, radionuclide-marked TAG-72 antibodies are used in the surgical treatment of colorectal tumours. With the help of the radionuclide-marked TAG-72 antibodies, one can determine if the tumour has been removed completely, which is an important factor for survival [10]. In addition, TAG-72 expression is clinically correlated with the aggressiveness and stage of the disease, and has a prognostic value in colorectal and breast cancer [12-16]. Some researchers have reported TAG-72 to be a good indicator in distinguishing malignant epithelial mesothelioma from serous papillary carcinoma [17]. Ordonez has used TAG-72 as a marker in order to differentiate 45 cases whether they had ovarian serous cell carcinoma or malignant mesothelioma. None of the samples with mesothelioma were stained, whereas the carcinomas of ovarian origin had different rates of staining [18].

Lin has indicated TAG-72 as an important marker for the differential diagnosis in the peritoneal fluid cytology, for the FIGO IIIA endometrial carcinomas, which have an extra uterine spreading pattern, in his guiding article for the pathologists, published in 2009. But he has recommended more caution in cases like endometriosis and endosalpingitis [19].

TAG-72 has also a special importance in guiding the pathological differentiation of endometrial and cervical cancer [20]. In one of these studies, researchers have claimed that the TAG-72 positivity is rare for endometrial hyperplasia and was not related to clinical regression and progression. There is a limited number of articles about TAG-72 expression in the endometrium. Mottolese et al. have observed in their study of hysterectomy materials [13] that of the 13 cases with a proliferative endometrium, 2 patients (15\%), of the 14 cases with a secretory endometrium, 9 patients (64\%), of the 27 cases with non-atypical hyperplasia, 6 patients (22\%), and of the 20 cases with endometrial carcinoma 19 patients $(95 \%)$ had reactivity.

In our series, of the 5 cases with secretory adenoma, there was no staining in 4 (80\%). There was also no staining in 4 cases with proliferative adenoma, 9 cases with simple non-atypical hyperplasia, and 10 cases with complex non-atypical hyperplasia. Of the $21 \mathrm{pa}$ tients with endometrial adenocarcinoma, 16 (76\%) were found to have immunoreactivity. In one of these studies, the researchers have claimed that the TAG-72 positivity is rare in endometrial hyperplasia, and it was not related to the progression or the clinical regression of the disease.

In our study, there was no correlation between the pattern and intensity of the immunoreactivity staining of TAG-72, and the traditional prognostic factors (stage, grade, myometrial invasion). With the one-way analysis of variance, there was a significant difference between the TAG-72 staining pattern and the age of the patient $(p=0.023)$.

There was no TAG-72 immunoreactivity in complex hyperplasia, simple hyperplasia, and the proliferative endometrium. A significant difference was found between the neoplastic and non-neoplastic groups in terms of intensity, pattern, and intensity + pattern $(p<0.001)$.

In our case study, based on a small group, the TAG72 expression was found to be highly statistically significant both for the pattern and intensity variables, in the differentiation of neoplastic- and non-neoplastic plus hyperplastic endometrium $(p<0.001)$.

In conclusion:

1. We have concluded that TAG-72 is a reliable parameter and marker for the differentiation of the neoplastic and non-neoplastic plus hyperplastic endometrium.

2. The marker TAG-72 is a reliable parameter and marker for the differentiation of the neoplastic endometrium from the non-neoplastic and hyperplastic endometrium.

3. There is a significant relationship between increasing age and the staining pattern of the TAG-72 expression.

4. Still, TAG-72 does not seem to be an independent prognostic factor for endometrial carcinoma. These results are encouraging for larger and more detailed studies in the future.

\section{The authors declare no conflict of interest.}

\section{References}

1. Tavassoli FA, Stratton MR Silverberg SG, et al. In WHO Classification of Tumors: Pathology and Genetics of Tumors of the Breast and Female Genital Organs, Tumors of the uterine corpus: Epithelial tumors and related lesions. Tavassoli FA, Stratton MR (eds.). IARC Press, Lyon 2003; 221-32.

2. Silverberg SG Problems in the differential diagnosis of endometrial hyperplasia and carcinoma. Mod Pathol 2000; 13: 309-27.

3. American College of Obstetricians and Gynecologists ACOG practice bulletin, clinical management guidelines for obstetrician-gynecologists, number 65, August 2005: management of endometrial cancer. Obstet Gynecol 2005; 106: 413-25.

4. Trimble CL, Kauderer J, Zaino R, et al. Concurrent endometrial carcinoma in women with a biopsy diagnosis of atypical endometrial hyperplasia: A Gynecologic Oncology Group study. Cancer 2006; 106: 812-9.

5. Lacey JV Jr, Chia VM. Endometrial hyperplasia and the risk of progression to carcinoma. Maturitas 2009; 63: 39-44.

6. Lacey JV Jr, Sherman ME, Rush BB, et al. Absolute risk of endometrial carcinoma during 20-year follow-up among women with endometrial hyperplasia. J Clin Oncol 2010; 28: 788-92.

7. Creasman W. Revised FIGO staging for carcinoma of the endometrium. Int J Gynaecol Obstet 2009; 105: 109

8. Azueta A, Gatius S, Matias-Guiu X. Endometrioid carcinoma of the endometrium: pathologic and molecular features. Semin Diagn Pathol 2010; 27: 226-40. 
9. Bartolazzi A, Mottolese M, Vocaturo A, et al. Expression of CAR-3 and TAG-72 macro molecules in normal and transformed endometrium: po tential diagnostic application in postmenopausal patients. Cancer Res 1991; 51: 3001-5.

10. Povoski SP, Hatzaras IS, Mojzisik CM, Martin EW. Oncologic the ranostics: recognition of this concept in antigen-directed cancer therapy for colorectal cancer with anti-TAG-72 monoclonal antibodies. Expert Rev Mol Diagn 2011; 11:667-70.

11. Colcher D, Horan Hand P, Teramoto YA, et al. Use of monoclonal antibod ies to define the diversity of mammary tumor viral gene products in virions and mammary tumors of the genus Mus. Cancer Res 1981; 41: 1451-9.

12. Povoski SP, Hatzaras IS, Mojzisik CM, et al. Antigen-Directed Cancer Surgery for Primary Colorectal Cancer: 15-Year Survival Analysis. Ann Surg Oncol 2012; 19: 131-89.

13. Mottolese M, Vocaturo A, Bartolazzi A, et al. Immunocyto diagnosis of atypical hyperplasia and endometrial carcinoma in postmenopausal women. Int J Cancer 1992; 51:869-72.

14. Epivatianos A, Poulopoulos A, Kayavis I, Papanayotou P. Tumor-associated glycoprotein 72 (TAG-72) expressions in salivary gland neoplasia: an immunohistochemical study using the monoclonal antibody (MAb) CC49. Oral Dis 2000; 6: 112-7.
15. Okamoto S, Okamoto A, Nikaido T, et al. Mesenchymalto epithelial transition in the human ovarian surface epithelium focusing on inclusion cysts. Oncol Rep 2009; 21: 1209-14.

16. Ouyang $\mathrm{M}, \mathrm{Wu} \mathrm{W}$, Zou Y, et al. Immunoreactivity and prognostic value of tumor associated glycoprotein 72 in primary gallbladder carcinoma. Surg Oncol 2010; 19: 82-7.

17. Ordóńez NG. Value of E-cadherin and N-cadherin immuno staining in the diagnosis of mesothelioma. Hum Pathol 2003; 34: 749-55.

18. Ordóńez NG. The diagnostic utility of immunohistochemistry and electron microscopy in distinguishing between peritoneal mesotheliomas and serous carcinomas: a comparative study. Mod Pathol 2006; 19: 34-48.

19. Lin O. Challenges in the interpretation of peritoneal cytologic specimens. Arch Pathol Lab Med 2009; 133: 739-42.

20. Alkushi A, Irving J, Hsu F, et al. Immunoprofile of cervical and endometrial adenocarcinomas using a tissue microarray. Virchows Arch 2003; 442: 271. 